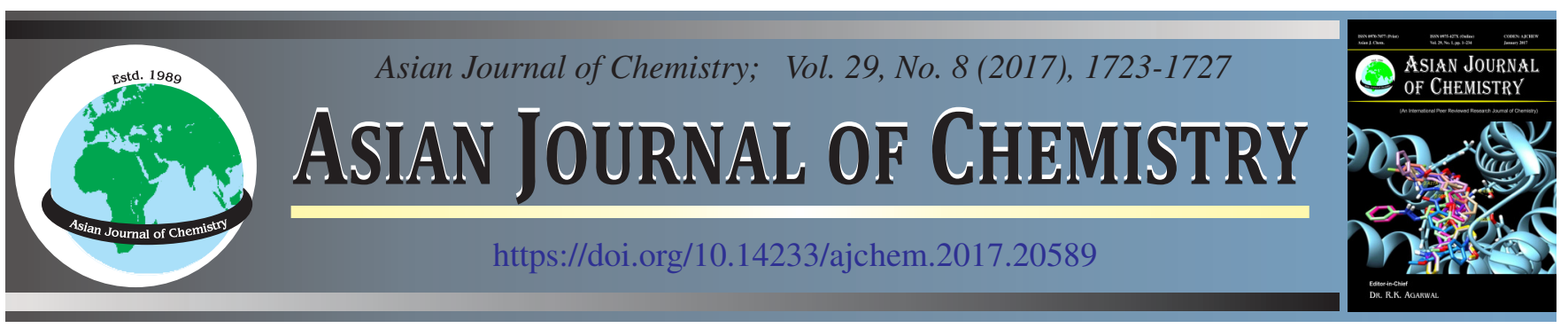

\title{
Catalytic Performance of Ammonium Salt of Molybdenum Heteropoly Acid Supported Silica for Oxidative Desulfurization of Benzothiophene, Dibenzothiophene and 4,6-Dimethyldibenzothiophene in Model Oil
}

\author{
Deeptiraj Pant, Ramswaroop Singh Thakur and Sunder Lal*
}

Department of Chemical Engineering, Maulana Azad National Institute of Technology, Bhopal-462 003, India

*Corresponding author: E-mail: sunderlalin@gmail.com

Received: 15 February 2017;

Accepted: 12 April 2017;

Published online: 12 June 2017;

AJC-18430

An ammonium salt of molybdenum heteropoly acid was loaded on silica support ( $\left.\mathrm{HPA}-\mathrm{SiO}_{2}\right)$, used as catalyst in oxidative desulfurization for removing benzothiophene (BT), dibenzothiophene (DBT) and 4,6-dimethyldibenzothiophene (4,6-DMDBT) from model oil. The structural properties of prepared catalyst were studied by using various analytical techniques; Fourier transforms infrared spectroscopy , $\mathrm{X}$-ray diffraction, scanning electron microscopy and thermogravimetric analysis. The results showed that the ammonium salt of molybdenum heteropoly acid highly dispersed on $\mathrm{SiO}_{2}$. The final catalyst exhibits good catalytic activity of oxidative desulfurization. The $94.6 \%$ of thiophene compounds of the model oil were removed under optimal conditions; temperature at $80{ }^{\circ} \mathrm{C}$, reaction time 100 min. The oxidation is decreased in order of DBT $>4,6-\mathrm{DMDBT}>\mathrm{BT}$.

Keywords: Benzothiophene, Dibenzothiophene, 4,6-Dimethyldibenzothiophene, Heteropoly acid, Model oil.

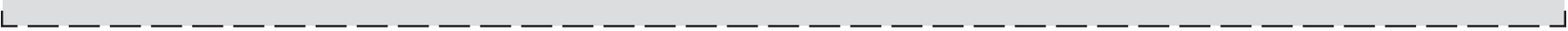

\section{INTRODUCTION}

Environmental regulations for sulfur emission limit for liquid fuels became more strict in last 20 years and more stringent legislation on the specification of sulfur content in liquid fuel have been issued over word wide. Production of ultra low sulfur liquid fuel is a challenge for petroleum industry because existing hydro desulfurization processes (HDS) for reducing sulfur in gasoline and diesel require critical operating conditions (high temperature and high pressure) for deep desulfurization. Hydro desulfurization processes is most common industrial process used in petroleum industry to reduce sulphur content of liquid fuels and has received extensive attention since its discovery in 1930's, It is a process in which light oils is heated, mixed with hydrogen and charged in to a reactor packed with a catalyst. At this temperature, some or all of the feed is convert in to vapour, depending on the boiling range of the feed and the pressure is the unit [1,2]. Liquid fuels contain sulfur in form of mercaptans, sulphides, disulfides and thiophenes. It is undesirable compound because it forms sulphur dioxide $\left(\mathrm{SO}_{2}\right)$ during fuel oil combustion [3]. The HDS has been fail to removing aromatic organo sulfur compounds, such as benzothiophene (BT), dibenzothiophene (DBT) and 4,6-dimethyldibenzothiophene due to their stearic hindrance [4-6]. The electron density of BT, DBT, 4,6-DMDBT shown in Table-1.
Therefore, many alternative non-hydrodesulfurization technologies, such as oxidation [7-9], adsorption [10-12], extraction [13], biodesulfurization [14], have been widely investigated. Among these, oxidative desulfurization, which operates under mild conditions without requiring hydrogen, is regarded as the promising and economical process [15]. This process is used to convert thiophene, benzenethiophene, dibenzothiophene and 4,6-dimethyldibenzothiophene into sulfones and sulfoxides in presence of oxidizing agent and sulfones and sulfoxides are easily separated by extraction with polar solvent [16-19]. The ODS process widely studied in various systems, such as organic acid [20], heteropolyoxo-metalates [21], ionic liquid [22,23], molecular sieve [24,25] and photocatalysts [26], heteropoly acid (HPA) catalysts [27-29], HPA catalysts, especially those having the keggin structure, have been determined to be very effective for the oxidation of sulfur containing compounds in a liquid-liquid two phase system. Li et al. [30] reported mesoporous silica pillared clay incorporated with phosphotungstic acid. Chamack et al. [31] reported a series of cesium salts of tungsten substituted molybdo-phosphoric acid, $\mathrm{Cs}_{\mathrm{x}} \mathrm{H}_{3-\mathrm{x}}\left[\mathrm{PMo}_{12-\mathrm{y}} \mathrm{WyO}_{40}\right],(\mathrm{x}=1-3, \mathrm{y}=2-1)$ supported on platelet SBA-15). Wu et al. [32] reported metal-modified $\left[\mathrm{PW}_{11} \mathrm{O}_{39}\left(\mathrm{H}_{2} \mathrm{O}\right) \mathrm{M}\right]^{5-}\left(\mathrm{M}=\mathrm{Ni}^{2+}\right.$ or $\left.\mathrm{Co}^{2+}\right)$ were incorporated into the mesoporous silica pillared clays (MSPC) which shows excellent performance in ODS. These catalysts showed the 
good performance in ODS system. In this work, an ammonium salt of molybdenum heteropoly acid (HPA) was synthesized and loaded on silica support. The porosity and large surface area of silica combine with heteropoly acid which have good redox properties and strong acidity The catalyst were systematically characterized by several techniques and applied on oxidative desulfurization process for removal of BT, DBT and 4,6-DMDBT under mild condition.

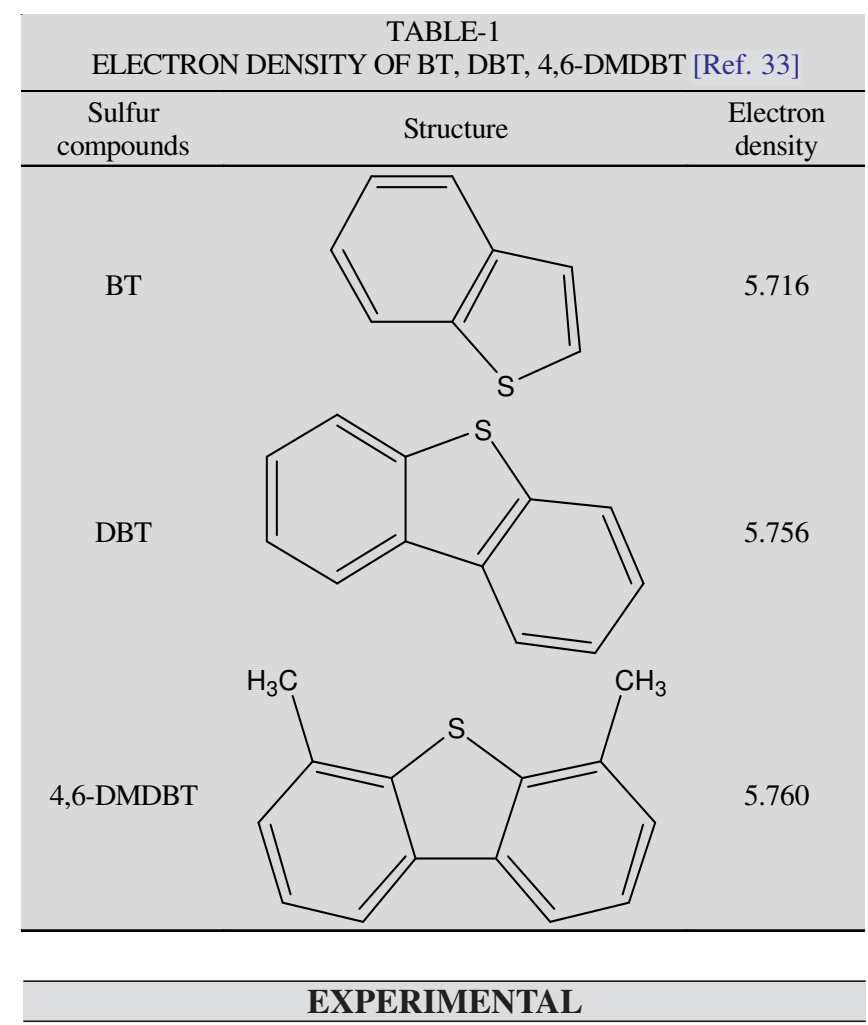

All the chemicals including hydroperoxide analytical reagent grade benzothiophene (BT), dibenzothiophene (DBT), 4,6-dimethyl-dibenzothiophene (4,6-DMDBT), ammonium heptamolybdate, $\left(\mathrm{NH}_{4}\right)_{6} \mathrm{Mo}_{7} \mathrm{O}_{24} \cdot 4 \mathrm{H}_{2} \mathrm{O}(4.24 \mathrm{~g}, 0.0034 \mathrm{~mol})$, diammonium hydrogen orthophosphate, $\left(\mathrm{NH}_{4}\right)_{2} \mathrm{HPO}_{4}(0.27 \mathrm{~g}$, $0.002 \mathrm{~mol})$, iso-octane, nitric acid, $\mathrm{SiO}_{2}$ purchased from Molychem company.

Preparation of model oil: Three model oils were prepared by dissolving benzothiophene, dibenzothiophene and 4,6dimethyl-dibenzothiophene separately into iso-octane to give a desired sulfur content (sulfur-contenting compounds concentration of 0.2 wt. $\%$.

\section{Preparation of catalyst}

Preparation of $\left(\mathrm{NH}_{4}\right)_{3} \mathrm{PMo}_{12} \mathrm{O}_{40}$ heteropoly acid (HPA): An ammonium salt of molybdenum heteropoly acid was prepared

according to the literature [34]. Aqueous solution of ammonium heptamolybdate, $\left(\mathrm{NH}_{4}\right)_{6} \mathrm{Mo}_{7} \mathrm{O}_{24} \cdot 4 \mathrm{H}_{2} \mathrm{O}(4.24 \mathrm{~g}, 0.0034 \mathrm{~mol})$ was prepared by dissolving it in $40 \mathrm{~mL}$ of water at $373 \mathrm{~K}$. Similarly an aqueous solution of diammonium hydrogen orthophosphate, $\left(\mathrm{NH}_{4}\right)_{2} \mathrm{HPO}_{4}(0.27 \mathrm{~g}, 0.002 \mathrm{~mol})$ was prepared in $20 \mathrm{~mL}$ of water. Then they were mixed and its $\mathrm{pH}$ was adjusted to 1.0 by addition of nitric acid. The yellow precipitate obtained was the ammonium salt of molybdenum heteropoly acid, $\left(\mathrm{NH}_{4}\right)_{3} \mathrm{PMo}_{12} \mathrm{O}_{40}$ (denoted by HPA). This suspension was directly used for the preparation of the heterogeneous catalyst.

Preparation of final catalyst: The silica $(50 \mathrm{~g})$ was added to $30 \mathrm{~g}$ of HPA solution. This was then kept under reflux conditions at $70{ }^{\circ} \mathrm{C}$ for $8 \mathrm{~h}$. The solid material which was filtered and dried was the final catalyst having $5 \%$ of the HPA. This final catalyst is denoted by $\mathrm{HPA}-\mathrm{SiO}_{2}$.

\section{Catalyst test}

Reaction: Three model oils were prepared by dissolving benzothiophene (BT), dibenzothiophene (DBT) or 4,6-dimethyldibenzothiophene (4,6-DMDBT) separately into iso-octane to give a desired sulfur content (sulfur-contenting compounds concentration of $0.2 \mathrm{wt}$. \%). In a typical run, $20 \mathrm{~mL}$ of model oil was placed in a three-neck flask. The reaction temperature was stabilized by oil bath. The catalyst and $30 \mathrm{wt} . \% \mathrm{H}_{2} \mathrm{O}_{2}$ were added to the flask successively to run the reaction. The samples were collected at an interval of $20 \mathrm{~min}$. Dibenzothiophene oxidize to form corresponding sulfoxides and sulfones in presence of oxidizing agent and catalyst is shown in Fig. 1.

Mechanism for sulfur removal from oil in the presence of ammonium salt of molybdophosphoric acid (HPA)-SiO $\mathrm{S}_{2}$ catalyst by ODS process shown in Fig. 2 [32]. (1) Firstly,

(2)

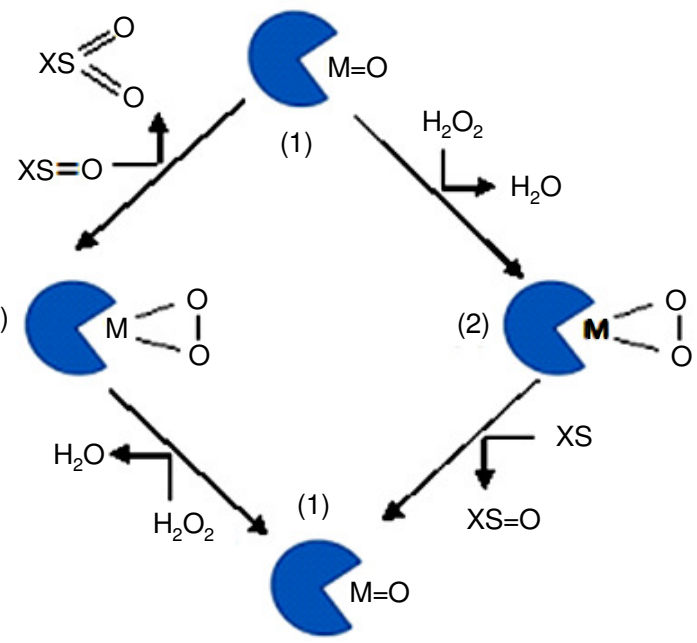

Fig. 2. Mechanism for the oxidation of organosulfur compound by $\mathrm{H}_{2} \mathrm{O}_{2}$ (oxidant) and $\mathrm{HPA}-\mathrm{SiO}_{2}$ (catalyst) [31]

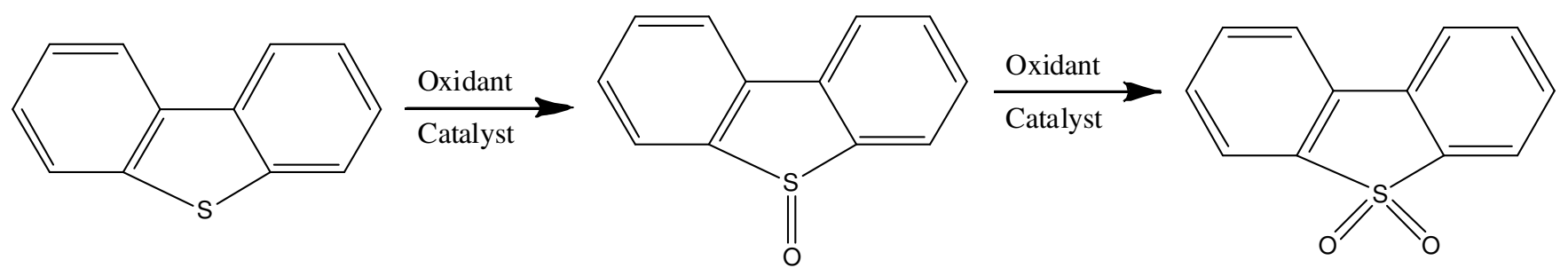

Fig. 1. Reaction of DBT in the catalytic oxidation 
addenda atom of POM take the oxygen from oxidant and forms peroxo species (2), the peroxo species donate an oxygen to organosulfur compound and oxidise it to organo sulfoxide and recovered as POM (1).

Reaction monitoring: To determine the concentration of the selected sulfur compound in the organic phase, approximately $0.5 \mathrm{~mL}$ of sample were withdrawn from the reactor at fixed time intervals and after phase separation the organic phase was analyzed by gas chromatography. GC equipped with a flame ionization detector, using a $30 \mathrm{~m}$. i.d. $0.32 \mathrm{~mm}$ HP-5 column. The main parameters were the following: carrier gas, nitrogen with a flow of $2 \mathrm{~mL} / \mathrm{min}$; injector temperature. $250{ }^{\circ} \mathrm{C}$ : detector temperature. $260{ }^{\circ} \mathrm{C}$ : temperature program, $40{ }^{\circ} \mathrm{C}$ or the first $5 \mathrm{~min}, 40-100^{\circ} \mathrm{C}$ at $10^{\circ} \mathrm{C} / \mathrm{min} .100-200{ }^{\circ} \mathrm{C}$ at $15^{\circ} \mathrm{C} / \mathrm{min}$, $200{ }^{\circ} \mathrm{C}$ for $5 \mathrm{~min}, 200-250{ }^{\circ} \mathrm{C}$ for $15 \mathrm{~min}$ [35].

\section{RESULTS AND DISCUSSION}

\section{Catalyst characterization}

Scanning electron microscope (SEM) of $\mathrm{HPA} / \mathrm{SiO}_{2}$ : The SEM analysis of catalyst has been taken on a JEOL JSM-840A. The powder sample is gold coated under vacuum to make it conducting for electrons. The SEM image (Fig. 3) confirms the dispersion of ammonium salt of molybdophosphoric acid (HPA) over silica surface and shows porous surface of the catalyst with high surface area.

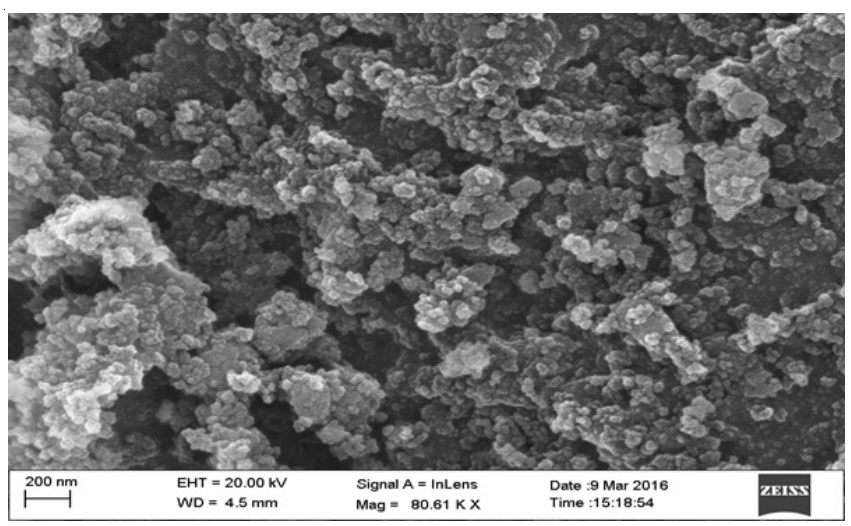

Fig. 3. SEM image of $\mathrm{HPA}-\mathrm{SiO}_{2}$ catalyst

FTIR analysis of the $\mathrm{HPA} / \mathrm{SiO}_{2}$ catalyst: The FTIR analysis was carried out on a Bruker Vector 22 instrument in the 4000$400 \mathrm{~cm}^{-1}$ wave number range. The FTIR spectrum of the final heterogeneous catalyst is shown in Fig. 4. The deposition of molybdenum heteropoly acid on the surface of the support was shown by the bands at 1401,1024 and $930 \mathrm{~cm}^{-1}$ which represent the stretching vibrations of $\mathrm{NH}_{4}{ }^{+}$ion, $\mathrm{P}-\mathrm{O}$ and Mo-O, respectively and the band at $780 \mathrm{~cm}^{-1}$ is attributed to stretching vibration of $\mathrm{Mo}=\mathrm{O}=\mathrm{Mo}$.

X-ray diffraction of $\mathrm{HPA} / \mathrm{SiO}_{2}$ : X-ray diffraction measurements of the catalyst were carried out on a Sietronics XRD diffractometer equipped with $\mathrm{Cu}-\mathrm{K}_{\alpha}(\lambda=1.54 \mathrm{~nm})$ radiation. The voltage and current applied to the X-ray tube were $40 \mathrm{kV}$ and $20 \mathrm{~mA}$, respectively and the sampling step was set at $0.05^{\circ}$ with scanning speed as $3 \% \mathrm{~min}\left(2 \theta=10^{\circ}\right.$ to $\left.80^{\circ}\right)$. The XRD pattern of the final catalyst, $\mathrm{HPA} / \mathrm{SiO}_{2}$ is shown in Fig. 5. X-ray diffraction measurements of the catalyst were carried out on a Sietronics XRD diffractometer equipped with $\mathrm{Cu}-\mathrm{K}_{\alpha}(\lambda=1.54$

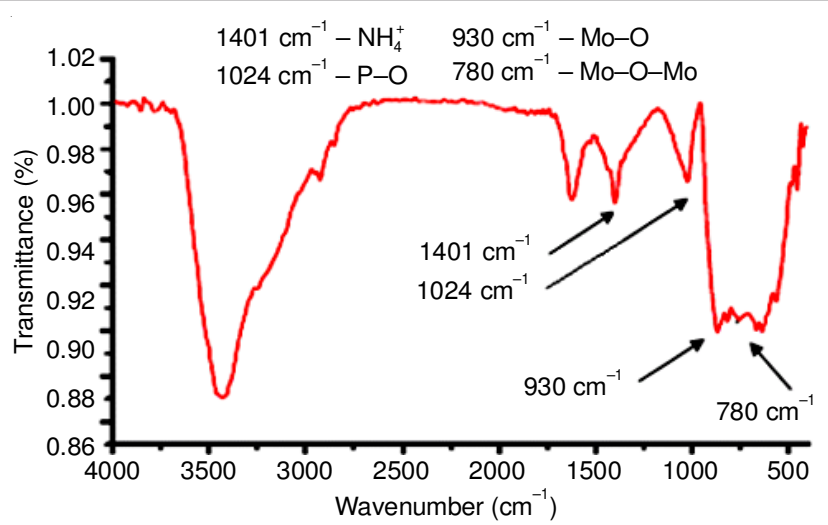

Fig. 4. FTIR of $\mathrm{HPA}-\mathrm{SiO}_{2}$ catalyst

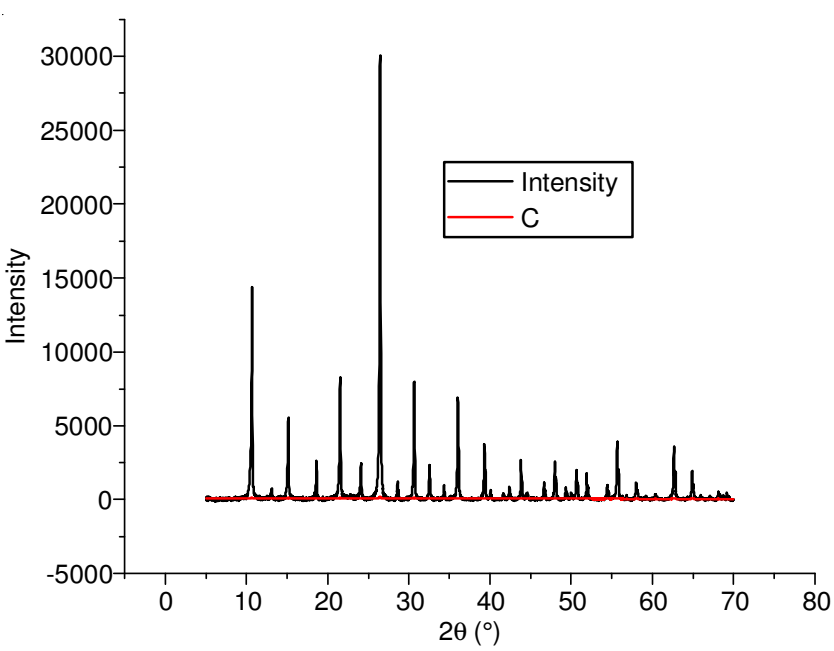

Fig. 5. X-ray diffraction of HPA- $\mathrm{SiO}_{2}$

$\mathrm{nm})$ radiation. The voltage and current applied to the X-ray tube were $40 \mathrm{kV}$ and $20 \mathrm{~mA}$, respectively and the sampling step was set at $0.05^{\circ}$ with scanning speed as $3 \%$ min $\left(2 \theta=10^{\circ}\right.$ to $\left.80^{\circ}\right) \cdot 2 \theta=10-20$ and $25-30$ correspond to the deposition of molybdenum heteropoly acid (HPA) [34].

Thermogravimetric analysis: The TGA analysis of the complex catalyst was carried out using a Perkin-Elemer instrument in $\mathrm{N}_{2}$ atmosphere. The TGA graph of $\mathrm{HPA} / \mathrm{SiO}_{2}$ catalyst is given in Fig. 6. The catalyst showed a considerable weight loss on heating till $250{ }^{\circ} \mathrm{C}$ while the corresponding catalyst were found to be stable till $500{ }^{\circ} \mathrm{C}$.

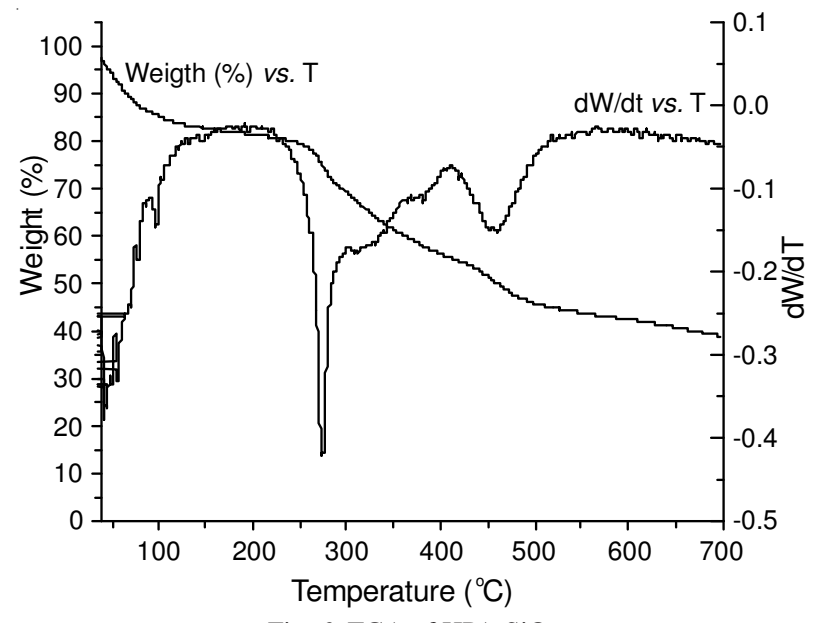

Fig. 6. TGA of $\mathrm{HPA}-\mathrm{SiO}_{2}$ 
Influence of reaction temperature on the catalytic performance of $\mathrm{HPA} / \mathrm{SiO}_{2}$ on ODS of BT: The influence of reaction parameters, such as the reaction temperature and $\mathrm{O} / \mathrm{S}$ molar ratio with reaction time were studied by using HPA/ $\mathrm{SiO}_{2}$ catalyst shown in Fig. 7.

Fig. 7 (a), (c), (e) shows the effect of temperature and $\mathrm{O} / \mathrm{S}$ molar ratio on oxidation of sulfur compounds under the experimental conditions at different molar ratio of 2, 3, 4, 5, with time at $80{ }^{\circ} \mathrm{C}$. With increasing the ratio from 2 to 3 , the sulfur removal increase up to $91.2,94.3$ and 92.1 in $100 \mathrm{~min}$ for oil containing BT, DBT and 4,6-DMDBT, respectively. Further increase in molar ratio up to 5 leads to decreasing the sulfur removal. The phenomenon may be attributed to the fact that there is a competition between the decomposition of $\mathrm{H}_{2} \mathrm{O}_{2}$ and the oxidation of sulfur compounds by $\mathrm{H}_{2} \mathrm{O}_{2}$ [15]. When the $\mathrm{O} / \mathrm{S}$ molar ratio was increased from 4 to 5 , the decrease of desulfurization activity was attributed to the water produced from oxidation reaction and thermal decomposition of $\mathrm{H}_{2} \mathrm{O}_{2}$, which inhibited the oxidation reaction. Therefore, the optimized $\mathrm{H}_{2} \mathrm{O}_{2} / \mathrm{BT}$ mole ratio as selected as 3 .

Fig. 7, (b) (d) (f) shows the effect of the amount of $\mathrm{H}_{2} \mathrm{O}_{2}$ on oxidation of sulfur compounds under the experimental conditions at $40,60,80$ and $100{ }^{\circ} \mathrm{C}$ with time. With increasing the temperature from 60 to 80 , the sulfur removal increases up to 91.5 , 94.6 and 92.5 for oil containing BT, DBT, 4,6DMDBT, respectively. It was indicated that the sulfur removal of BT increased with increasing time at different temperatures. At beginning of reaction, the less $\mathrm{H}_{2} \mathrm{O}_{2}$ decomposed. It was known that the higher the reaction temperature was, the faster reaction rate was. Therefore, the sulfur removal followed order of $40{ }^{\circ} \mathrm{C}<60{ }^{\circ} \mathrm{C}<80^{\circ} \mathrm{C}$. After $100{ }^{\circ} \mathrm{C}$ the sulfur removal decreased. The phenomenon attributed to decomposition of $\mathrm{H}_{2} \mathrm{O}_{2}$. As the reaction progressed, the higher temperature could lead to more decomposition of $\mathrm{H}_{2} \mathrm{O}_{2}$ and worse utilization of $\mathrm{H}_{2} \mathrm{O}_{2}$. On the basis of results, the reaction for 100 min at 80 ${ }^{\circ} \mathrm{C}$ is chosen as an optimal condition for the desulfurization process. The maximum sulfur removal at optimal condition in presence of $\mathrm{HPA} / \mathrm{SiO}_{2}$ catalyst is shown in Table-2.

\begin{tabular}{lc}
\multicolumn{2}{c}{ TABLE-2 } \\
\multicolumn{2}{c}{ SULFUR REMOVAL AT OPTIMAL CONDITIONS } \\
\hline \multicolumn{1}{c}{ Compounds } & Conversion (\%) \\
\hline Benzothiophene (BT) & 91.5 \\
Dibenzothiophene (DBT) & 94.6 \\
4,6-Dimethyldibenzothiophene (4,6-DMDBT) & 92.5 \\
\hline
\end{tabular}

\section{Conclusion}

As oxidative desulfurization ammonium salt of molybdenum heteropoly acid were successfully impregnated on silica. FTIR spectra and SEM confirms the deposition of HPA over silica support. TGA shows high thermal stability of catalyst. After 100 min the sulfur compounds BT, DBT and 4,6-DMDBT are oxidized up to $91.5,94.6$ and 92.5 , respectively. The oxidation reactivity decreased in order of DBT $>4,6-\mathrm{DMDBT}>\mathrm{BT}$. The solid catalyst was separated easily from the oxidation system by centrifugation and could be recycled for seven times without obvious decreasing in oxidation activity. The HPA/ $\mathrm{SiO}_{2}$ oxidation system was effective to remove aromatic sulfur-
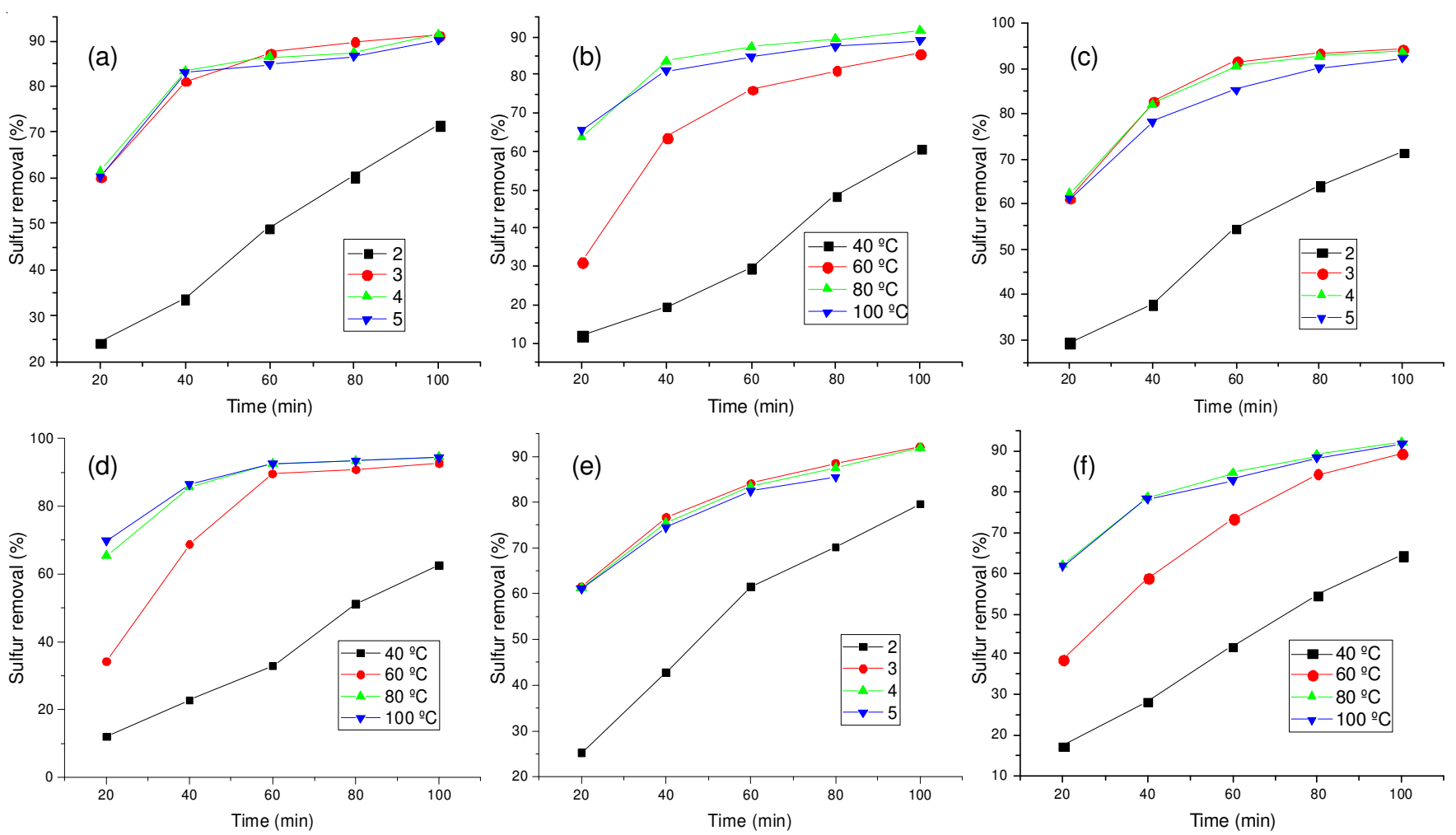

Fig. 7. (a) Influence of $\mathrm{O} / \mathrm{S}$ molar ratio on performance of catalyst $\left(\mathrm{HPA}-\mathrm{SiO}_{2}\right)$ in $\mathrm{ODS}$ of $\mathrm{BT}$ at temperature $80{ }^{\circ} \mathrm{C}$ (b) Influence of temperature at O/S molar ratio 3 on performance of catalyst in ODS of BT(c) Influence of O/S molar ratio on performance of catalyst in ODS of DBT at temperature $80^{\circ} \mathrm{C}$ (d) Influence of temperature at $\mathrm{O} / \mathrm{S}$ molar ratio 3 on performance of catalyst in ODS of DBT (e) Influence of $\mathrm{O} / \mathrm{S}$ molar ratio on performance of catalyst in ODS of 4,6-DMDBT BT at temperature $80^{\circ} \mathrm{C}$ (f) Influence of temperature at $\mathrm{O} / \mathrm{S}$ molar ratio 3 on performance of catalyst in ODS of 4,6-DMDBT 
containing compounds from hydro treated diesel oil, the sulfur content decrease up to $96 \%$ at mild operating conditions.

\section{REFERENCES}

1. I.V. Babich and J.A. Moulijn, Fuel, 82, 607 (2003); https://doi.org/10.1016/S0016-2361(02)00324-1.

2. J.M. Campos-Martin, M.C. Capel-Sanchez, P. Perez-Presas and J.L.G. Fierro, J. Chem. Technol. Biotechnol., 85, 879 (2010); https://doi.org/10.1002/jctb. 2371.

3. Y. Shiraishi, T. Naito, T. Hirai and I. Komasawa, Ind. Eng. Chem. Res., 41, 4376 (2002); https://doi.org/10.1021/ie010620o.

4. N.D. McNamara, G.T. Neumann, E.T. Masko, J.A. Urban and J.C. Hicks, J. Catal., 305, 217 (2013); https://doi.org/10.1016/j.jcat.2013.05.021.

5. O. González-García and L. Cedeño-Caero, Catal. Today, 148, 42 (2009); https://doi.org/10.1016/j.cattod.2009.03.010.

6. H. Lü, W. Ren, W. Liao, W. Chen, Y. Li and Z. Suo, Appl. Catal. B, 138-139, 79 (2013); https://doi.org/10.1016/j.apcatb.2013.02.034.

7. W. Zhang, H. Zhang, J. Xiao, Z.X. Zhao, M.X. Yu and Z. Li, Green Chem., 16, 211 (2014); https://doi.org/10.1039/C3GC41106K

8. J. Xiao, L.M. Wu, Y. Wu, B. Liu, L. Dai, Z. Li, Q.B. Xia and H.X. Xi, Appl. Energy, 113, 78 (2014);

https://doi.org/10.1016/j.apenergy.2013.06.047.

9. B.Y. Zhang, Z.X. Jiang, J. Li, Y.N. Zhang, F. Lin, Y. Liu and C. Li, J. Catal., 287, 5 (2012) https://doi.org/10.1016/j.jcat.2011.11.003.

10. R.T. Yang, A.J. Hernandez-Maldonado and F.H. Yang, Science, 301, 79 (2003); https://doi.org/10.1126/science. 1085088 .

11. J.-H. Shan, X.-Q. Liu, L.-B. Sun and R. Cui, Energy Fuels, 22, 3955 (2008); https://doi.org/10.1021/ef800296n

12. K.S. Triantafyllidis and E.A. Deliyanni, Chem. Eng. J., 236, 406 (2014); https://doi.org/10.1016/j.cej.2013.09.099.

13. A. Bösmann, L. Datsevich, A. Jess, A. Lauter, C. Schmitz and P. Wasserscheid, Chem. Commun., 2494 (2001); https://doi.org/10.1039/b108411a.

14. M.A. Dinamarca, A. Rojas, P. Baeza, G. Espinoza, C. Ibacache-Quiroga and J. Ojeda, Fuel, 116, 237 (2014); https://doi.org/10.1016/i.fuel.2013.07.108.

15. W. Ding, W. Zhu, J. Xiong, L. Yang, A. Wei, M. Zhang and H. Li, Chem. Eng. J., 266, 213 (2015); https://doi.org/10.1016/j.cej.2014.12.040.

16. C. Shu, T. Sun, H. Zhang, J. Jia and Z. Lou, Fuel, 121, 72 (2014); https://doi.org/10.1016/j.fuel.2013.12.037.
17. A. Stanislaus, A. Marafi and M.S. Rana, Catal. Today, 153, 1 (2010); https://doi.org/10.1016/j.cattod.2010.05.011.

18. G. Zhang, F. Yu and R. Wang, Coal, 51, 196 (2009).

19. H. Song, X. Wan, M. Dai, J. Zhang, F. Li and H. Song, Fuel Process. Technol., 116, 52 (2013); https://doi.org/10.1016/i.fuproc.2013.04.017.

20. M.W. Wan and T.F. Yen, Appl. Catal. A, 319, 237 (2007); https://doi.org/10.1016/j.apcata.2006.12.008.

21. M. Zhang, W. Zhu, S. Xun, H. Li, Q. Gu, Z. Zhao and Q. Wang, Chem. Eng. J., 220, 328 (2013); https://doi.org/10.1016/j.cej.2012.11.138.

22. W. Zhu, P. Wu, L. Yang, Y. Chang, Y. Chao, H. Li, Y. Jiang, W. Jiang and S. Xun, Chem. Eng. J., 229, 250 (2013); https://doi.org/10.1016/j.cej.2013.05.115.

23. W. Jiang, W. Zhu, Y. Chang, Y. Chao, S. Yin, H. Liu, F. Zhu and H. Li, Chem. Eng. J., 250, 48 (2014); https://doi.org/10.1016/j.cej.2014.03.074.

24. Z.E.A. Abdalla and B. Li, Chem. Eng. J., 200-202, 113 (2012); https://doi.org/10.1016/j.cej.2012.06.004.

25. M. Zhang, W. Zhu, H. Li, S. Xun, W. Ding, J. Liu, Z. Zhao and Q. Wang, Chem. Eng. J., 243, 386 (2014); https://doi.org/10.1016/j.cej.2013.12.093.

26. W. Zhu, Y. Xu, H. Li, B. Dai, H. Xu, C. Wang, Y. Chao and H. Liu, Korean J. Chem. Eng., 31, 211 (2014); https://doi.org/10.1007/s11814-013-0224-3.

27. M. Te, C. Fairbridge and Z. Ring, Appl. Catal. A, 219, 267 (2001); https://doi.org/10.1016/S0926-860X(01)00699-8.

28. H. Li, L. He, J. Lu, W. Zhu, X. Jiang, Y. Wang and Y. Yan, Energy Fuels, 23, 1354 (2009); https://doi.org/10.1021/ef800797n.

29. M. Arias, D. Laurenti, C. Geantet, M. Vrinat, I. Hideyuki and Y. Yoshimura, Catal. Today, 130, 190 (2008); https://doi.org/10.1016/j.cattod.2007.08.017.

30. B. Li, Z. Liu, J. Liu, Z. Zhou, X. Gao, X. Pang and H. Sheng, J. Colloid Interface Sci., 362, 450 (2011): https://doi.org/10.1016/i.jcis.2011.07.025.

31. M. Chamack, A.R. Mahjoub and H. Aghayan, Chem. Eng. J., 255, 686 (2014); https://doi.org/10.1016/i.cej.2014.06.054.

32. N. Wu, B. Li, Z. Liu and C. Han, Catal. Commun., 46, 156 (2014); https://doi.org/10.1016/j.catcom.2013.12.013.

33. S. Otsuki, T. Nonaka, N. Takashima, W.H. Qian, A. Ishihara, T. Imai and T. Kabe, Energy Fuels, 14, 1232 (2000); https://doi.org/10.1021/ef000096i.

34. K.M. Reddy, N. Lingaiah, K.N. Rao, N. Rahman, P.S. Sai Prasad and I. Suryanarayana, Appl. Catal. A, 296, 108 (2005); https://doi.org/10.1016/j.apcata.2005.08.016.

35. P. De Filippis and M. Scarsella, Energy Fuels, 17, 1452 (2003); https://doi.org/10.1021/ef0202539. 